
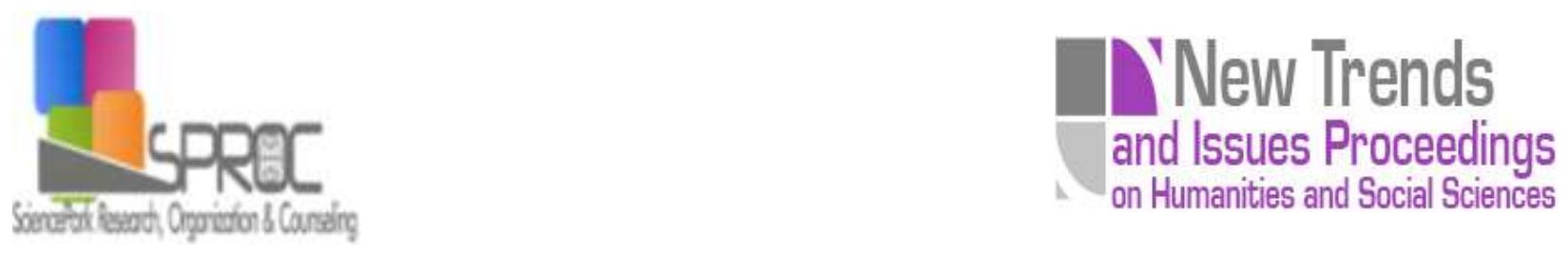

E

\title{
A participatory research on the role of the school as an agent for reflection and social change
}

Donatella Donato ${ }^{\text {** }}$

Suggested Citation:

E $\quad$ E New Trends and Issues Proceedings on Humanities and Social Sciences.

Abstract

E

* $\mathrm{EE}$

E Donatella Donato 
and Issues Proceedings on Humanities and Social Sciences.

1. Introduction 
and Issues Proceedings on Humanities and Social Sciences.

2. The Field of Research

cabañas 
and Issues Proceedings on Humanities and Social Sciences.

3. The school

los payos 


\section{The project "Fa Molts anys al Cabanyal"}

Fa Molts anys al Cabanyal 


\section{Design for Change}


and Issues Proceedings on Humanities and Social Sciences. 
and Issues Proceedings on Humanities and Social Sciences.

\section{References}

\& Cultural Geography 8

Educational Theory 49

Anthropology \& Education Quarterly 39

International Journal of Urban and Regional Research 38

New left review 69

$\mathrm{E}$

Cities 26

Urban Studies Research, 1,

Zainak.

Cuadernos de Antropología-Etnografía 32

A pedagogy for liberation: Dialogues on transforming education

El cabanyal: Un barrio patrimonial a rehabilitar 